\title{
Cultural Revolution: Mykhail Semenko, Ukrainian Futurism and the "National" Category
}

Author(s): Oleh S. Ilnytzkyj

Source: Kyiv-Mohyla Humanities Journal 4 (2017): 45-52

Published by: National University of Kyiv-Mohyla Academy

http://kmhj.ukma.edu.ua/ 


\title{
Cultural Revolution: Mykhail Semenko, Ukrainian Futurism and the "National" Category
}

\author{
Oleh S. Ilnytzkyj \\ Professor Emeritus, \\ University of Alberta
}

\begin{abstract}
This paper examines Mykhail Semenko's Futurist manifestos that developed an opposition between "national" and "international" art, and specifically called "national" art provincial and retrograde. In promoting the international European avant-garde, Semenko's essays demonstrate how consistently he championed a contemporary and modern Ukrainian culture in the face of home-grown conservatism.
\end{abstract}

Key Words: Mykhail Semenko, Ukrainian Futurism, Cultural Revolution, Avant-Garde.

\section{唡}

This paper is about Ukrainian Futurism as a form of aesthetic and cultural dissent within the Ukrainian national revolution. I approach the revolution not just as the political events of 1917 but as an extended social and cultural process that had earlier roots. The discussion is limited to texts by Mykhail Semenko, the founder of Ukrainian Futurism: the first two are from 1914 and a third is from 1927. The purpose is to explore how Ukrainian Futurism targeted the "national" category for criticism at a time when Ukrainians were struggling to create a national culture and state. ${ }^{1}$

During Futurism's heyday and in years later, mainstream Ukrainian critics and writers interpreted the Futurist attack on the "national" category as anti-Ukrainian. It was, in fact, a well-intentioned, internal critique of Ukrainian culture. The disconnect between Semenko and his contemporaries lay in the fact that he saw art (and specifically the avant-garde) as a quintessentially international process — not a national phenomenon. In fact, Ukrainian Futurism (like the Italian and Russian movements) went a step further and viewed the national tradition as an impediment to innovation, and by extension to a modern Ukrainian culture. Unlike most of Futurism's adversaries in the cultural field, Ukrainian Futurism did not seek to restore or recover anything in the old culture (be it European or Ukrainian); it was dedicated to creating new art and new values through an intramural struggle with Ukrainian conservative

1 The current paper draws on aspects of my book: Oleh S. Ilnytzkyj, Ukrainian Futurism, 1914-1930:

A Historical and Critical Study (Cambridge, Mass.: Harvard University Press, 1997). It was first presented at a conference on "Ukrainian Statehood 1917-1921: Institutions and Individuals," Columbia University, Harriman Institute, on February 25, 2017. 
cultural forces. It wanted a Ukrainian cultural revolution, not a "national" art. The movement espoused endless artistic change or permanent cultural revolution. ${ }^{2}$

One of the important questions for Ukraine, just before and after 1917, came down to the following: How, on what basis, and through what kind of cultural practices was the Ukrainian nation and Ukrainianness (ukrainstvo) to be institutionalized in the modern era?

From approximately 1900 to 1927 a variety of answers proliferated. There is no denying that the older populist ideal of creating a culture of and in the service of the "people," which defined the second half of the 19th century, began giving way at the end of that century to the notion of a "high" Ukrainian culture, a culture of and by the intelligentsia, a phenomenon that was crystalized by Ukrainian Modernism. The level of social engagement demanded from the artist had begun to wane, while the demand for high quality artistic artefacts increased. Ukrainian culture/literature was beginning to take shape as a self-conscious national institution, with the ambition of competing with analogous national European institutions, and, at long last, taking the place of Russian imperial culture. At this stage, artists were vying more and more for the attention of cultural connoisseurs and less and less for the attention of the masses. The function of art was defined by its ability to represent the nation with its finest works rather than by its patriotic or social message. The pursuit of beauty, of formal innovation, of art for art's sake, and the growing autonomy of the artist in society (including women writers and their gendered themes) was a major turning point in Ukrainian cultural life just before the revolution.

These transformations created anxiety not only among the populists and realists, but also among some Modernist adherents of the cult of beauty. There was a sense that art and literature might be in danger of becoming socially and politically irrelevant, and lose its Ukrainian authenticity. The Ukrainian national revolution, both as something anticipated and then, suddenly, as a reality, required, in the eyes of these people, a "national" art and literature. Tradition, cultural roots, connection to the people - these were some of the criteria that defined "national" art. In short, the "Europeanization" of Ukrainian letters - a major achievement of the Modernist period - was beginning to be perceived as a potential danger to the development of a uniquely Ukrainian literature and culture.

Into this creative but tense intellectual climate entered Mykhail Semenko with his Futurism in 1914. As I have noted, Ukrainian literature had seen sharp debates on the issue of the new art before Semenko's time. "Moloda muza" had inspired hot polemics and opinions; Serhii Yefremov was outraged by the new Modernist trends; Ivan Nechui-Levytskyi decried decadence; Ivan Franko debated Mykola Voronyi and scolded him for his aestheticism. In addition, Ukrainians were aware of the artistic debates in Europe, including those that had taken place in the Russian empire. Still, nothing prepared the Ukrainian reader and writer for Semenko's Futurist manifesto, "Sam" (I Alone), which appeared in Kyiv in February 1914. What is interesting to note in the quote below is how Semenko depicts the current Ukrainian cultural condition, how he characterizes his audience, and the artistic standards that rule Ukrainian society. His statement is social but in an aggressive and transgressive way. 


\section{Alone}

Hey, man, listen here! Listen here, I say. You're really strange, man. I'd like to tell you a few things about art and about things that relate to it, just a few words. Nothing can be better than talking with you about art, man. I clutch my sides and laugh. I reel with laughter. Your appearance is strange, man! Oh, you're funny as hell. Ah, it's terribly boring to be with you... I don't want to talk to you. You raise your greasy Kobzar and say: here is my art. Man, I'm embarrassed for you... You bring me debased 'ideas' about art and it makes me sick. Man, art is something you haven't even dreamt of. I want to tell you, that where there is a cult, there is no art. And most importantly, it [art] doesn't fear attack. Quite the contrary. It is strengthened when attacked. But you've latched on to your Kobzar, which smells of wagon grease and lard, and you think that your reverence will protect it. Your reverence has killed it and there is no way to resurrect it. Who is enthusiastic about it [the Kobzar] now? Primitive men, precisely of your type, who read [the newspaper] Rada [Council]. Man, time turns Titans into worthless Lilliputians, and their place now is in the annals of scholarly institutions. Living among you, one falls decades behind the times. I don't accept that type of art. How can I revere Shevchenko [the author of the 1840 Kobzar], when I see that he is under my feet? I can't pull veins of reverence from my body for months at a time the way you do for a man who, because he is a contemporary factor, is [therefore] a deeply repulsive phenomenon. Man, I want to tell you that right now, as I write this, I find it loathsome to pick up our papers. If I don't tell you what's on my mind, then I'll suffocate in the atmosphere of your 'sincere' Ukrainian art. I wish it would die. Such is your jubilee celebration. That's all there is left of Shevchenko. But, neither can I avoid my own celebration.

I burn my Kobzar. ${ }^{3}$

Let us reflect on what Semenko declared.

First, we should recall that 1914 marked the 1ooth anniversary of Taras Shevchenko's birth, Ukraine's national poet, an event the Russian empire discouraged from being celebrated. For Semenko, however, the subject is clearly and unmistakably "Art" (as an institution) and its status in Ukraine. According to him, Ukraine has a cult and ritual veneration, but no real art. This is not Shevchenko's fault, it is society's. Semenko's addressee is a ludicrous man who elicits both amusement and depression. The Kobzar, which is soiled from handling (but not necessarily reading) is put forth by the primitive man as the current definition and formula for art. Semenko is embarrassed by the argument.

But what is "Art," according to Semenko? It is a process tempered through struggle and polemics; an attack like Semenko's on Shevchenko is, by definition, meant to create space for 
a new art. The cult killed the Kobzar, which was the definition of art in an earlier era. Jubilee celebrations are all that is left of Shevchenko - who is no longer an artist but a cult figure.

Semenko links the man with primitive artistic instincts to the newspaper Rada (published in Kyiv between September 1906 to August 1914) and the Ukrainian periodic press in general, creating an expansive picture of social and cultural stagnation.

The factor of time and, more specifically, the idea of progress plays an important role in Semenko's argument: he says, that the passage of time turns giants into midgets; Shevchenko, a former giant, now belongs in the annals of learned societies; Semenko, as a Ukrainian, finds himself in danger of falling behind the times within his milieu. Shevchenko is a repulsive phenomenon because he continues to be a present-day artistic authority for many people. Semenko finds himself suffocating in this atmosphere of "sincere Ukrainian art": he wants to see it dead, so he can survive as an artist.

Finally, Semenko celebrates the Shevchenko jubilee by burning the grubby Kobzar, the emblem of the cult. This gesture could be read as a liberation of Shevchenko from a cult, in which his Kobzar serves a holy book instead of literature. By not showing reverence, by attacking the cult, Semenko frees Shevchenko as a literary "giant."

Some of these ideas were reiterated in a less incendiary form in Semenko's publication Kvero-futuryzm (March 1914), where he draws an explicit link between "national" artistic practices and lack of innovation.

We desire, by conscious means [shtuchnym rukhom], to bring our art closer to those frontiers of universal art where a new era is beginning. At the very least, art should be in step with Life, but now it is falling behind. And our Ukrainian art is so shamefully retrograde in its vulgar routine and slavish mustiness that it is not deserving of the name... [Art] can neither be Ukrainian nor anything else... National traits in art are a sign of its backwardness. ${ }^{4}$

Semenko's contemporaries clearly did not read his 1914 manifestos in the light he might have intended. His style was an impediment to a calm reception and the political situation in the Russian Empire made everyone highly sensitive to "national" issues. I will not recapitulate here the hysterical reaction by the critics of the journal Ukrainska khata (specifically Mykyta Sriblianskyi and Mykola Yevshan), who called Semenko an idiot and a national traitor. ${ }^{5}$ What is of interest to us is their need to justify "sincere Ukrainian art." In response to Semenko's call for an international orientation, Yevshan declared: "A new creativity, well and good. But on what foundation (na yakomu grunti)?" ${ }^{2} \mathrm{He}$ then affirmed a "national" orientation, maintaining that little was gained by following "European fashions." Sriblianskyi concurred: "We had all the most fashionable products of Europe, we discussed [her] wisest words, but our Ukrainian cause -

4 Mykhail Semenko, Kvero-futuryzm. Poezopisni [Quero-Futurism. Poem-Songs] (Kyiv: Kvero, 1914), 1-2.

$5 \quad$ For details, see Ilnytzkyj, Ukrainian Futurism, 3-27.

6 Mykola Yevshan, “'Suprema Lex.' Slovo pro kulturu ukrainskoho slova ['Suprema Lex.' A Word about the Culture of the Ukrainian Word]," Ukrainska khata 3-4 (1914): 271. 
'weeps like an orphan by the Dnipro."' 7 Yevshan glanced at the modern writings and sighed: "It is a pity that there is no one who might defend the Ukrainian creative idea." ${ }^{8}$ He elaborated:

This then is precisely the problem: the Ukrainian creative idea has begun to chase electric lamps, not having learned to examine life properly in the light of a gas lamp. The blinding light has had a bad effect on the eyes and they squint and cannot see the "nearest of objects." The "nearest of objects" in literature is the culture of the native word, that natural soil without which every creative work must emerge stunted and useless. ... Let us reach for that beauty which contains the soul and thoughts of the Ukrainian people!!9

Despite his revolutionary manifestos of 1914, Semenko completely missed out on the initial year of the revolution itself. With the outbreak of WWI, he was drafted into the Tsarist army and sent to the Far East, finding himself in places like Vladivostok, Harbin, Suchan (later known as Partizansk). He arrived in Ukraine only in December 1917, spending a few months in his native Kybyntsi (Poltava region), appearing in Kyiv in April 1918, when Hetman Skoropadskyi was assuming control. He became immediately active in literary and cultural life, publishing poetry and reviews, siding mostly with people close to the leftist Borotbist movement. With the advent of Soviet power, Semenko was chosen to become the editor of the very first Soviet Ukrainian art and literature periodical Mystetstvo (May to July 1919). He was briefly placed under arrest in August 1919 by Denikin's forces on suspicion of being a member of the communist party.

The history of Ukrainian Futurism during the 1920s is complex, with the greatest successes coming in the latter part of the decade. For our purposes, it will suffice to jump to the year 1927 when Semenko published Bumeranh (Boomerang), a collection of essays by fellow avantgardists, among which was one of his own dedicated to the perils of nationalism in art. It was titled: "Reflections About Why Ukrainian Nationalism is Bad for Ukrainian Culture, or, Why Internationalism is Good for It." This was an argument for an art that would have significance beyond the borders of Ukrainian national culture and, by extension, a critique of those who might be "pleased by the [current] parameters of Ukrainian culture." ${ }^{10}$ The essay once again painted an image of a retrograde Ukrainian culture precisely because it limited its horizons to the "national."

How did Semenko define "nationalism" and "internationalism"?

Ukrainian nationalism (he also uses the word "chauvinism") is equated with khutorianstvo and malorosiianstvo: the first implying parochialism and narrow-mindedness; the second literally meaning "Little Russianness," hinting at a subordinate cultural relationship to Russia,

7 Mykyta Sriblianskyi, "Etiud pro futuryzm [An Etude about Futurism]," Ukrainska khata 6 (1914): 463.

8 Yevshan, “Suprema Lex,” 272.

9 Yevshan, “Suprema Lex," 277.

10 Semenko, Mykhail, "Mirkuvannia pro te, chym shkidlyvyi ukrainskyi natsionalizm dlia ukrainskoi kultury, abo chym korysnyi internatsionalizm dlia nei zh [Reflections about Why Ukrainian Nationalism is Bad for Ukrainian Culture, or, Why Internationalism is Good for It]," Bumeranh 1 (1927): 4, 5. On the history of Bumeranh, see Ilnytzkyj, Ukrainian Futurism, 109-15. 
or an immature form of Ukrainianness. The problem with "nationalism," says Semenko is that it "Locks us into a circle of provincial interests, ideas and preferences" and distorts the very idea of "Europe." He emphasizes: "Every 'European' idea and novelty, [when] filtered through this type of parochialism, hangs on the neck of Ukrainian culture, like last year's shawl, and 'Europe' fits [Ukrainian culture] about as much as the words 'merci' and 'pardon' in the novels or feuilletons of [Mykola] Khvyliovyi and Arkadii Liubchenko..."11

The manifestations of parochialism in Ukraine take several forms. Semenko enumerates the fondness for Ukrainian choirs ("Dumka"); the cult of Shevchenko (with his portraits covered in traditional ritual cloths, i.e., rushnyky); and Marxist worker and peasant organizations like "Hart" and "Pluh." "In short, every simplification of culture regardless of its [political] color, including the Red and ending with the Proletarian." ${ }^{12}$ He also mentions the Ivan Franko Theatre (Teatr im. Franka), the Ukrainian Opera, and the many cultural societies named in honour of Mykola Leontovych. He calls all this disdainfully: Europe a la Ukraine (evropeiske po-ukraisnky). ${ }^{13}$ Turning to his readers, he says:

As you can see, your Ukraine is rather sad... If we remain satisfied with these parameters of Ukrainian culture, make them the starting point, defend them and elaborate on them, plus dress them up in some coherent theory, add an appropriate superstructure, then we will arrive at that nationalism that leads toward our native parochialism (ridnoho khutorianstva); [we will have] a provincial "Europeanism" for the underprivileged. Needless to say, those who are trying to build a proletarian culture with this baggage face an unenviable task..$^{14}$

For Semenko, nationalism and chauvinism is ultimately any movement in Soviet Ukrainian culture that refuses to go beyond "purely national creative preoccupations" or, as he cleverly also puts it, any phenomena that is not "digested by the native gut" (shcho vykhodyt z pevnykh mezh chysto-natsionalnykh tvorchykh kompleksiv i ne peretravlene $v$ ridnomu shlunkovi). ${ }^{15}$ Nationalism is a movement that does not "support what is innovative in culture," and expects "to build the culture of the proletariat by using the folksong." 16

When it came to identifying, what was "international" in Ukrainian culture, Semenko, naturally, listed all forms of Ukrainian Futurism, past and present, including his closest associates Mykola Bazhan, Geo Shkurupii, Oleksa Slisarenko, the All-Ukrainian Photo Cinema Directorate (VUFKU, Vseukrainske Foto Kino Upravlinnia), where he had worked a few years earlier. These people and institutions “...stand unwaveringly on the positions of internationalism, changing the direction of Ukrainian culture, [and are] in constant struggle with home-grown symbolism,

\footnotetext{
11 Semenko, "Mirkuvannia," 3.

12 Semenko, "Mirkuvannia," 4.

13 Semenko, "Mirkuvannia," 4.

14 Semenko, "Mirkuvannia," 4-5.

15 Semenko, "Mirkuvannia," 7.

16 Semenko, "Mirkuvannia," 8.
} 
aestheticism, and attempts to canonize academism, under all kinds of slogans." ${ }^{17}$ Les Kurbas was also singled out as someone whose theatrical work went well beyond "not only the theatre as such, but beyond the boundaries of national culture." 18 " $[\mathrm{T}]$ his international current in Ukrainian culture, moving within the coordinates of national culture with all its reactionary elements, has broken through into universal (svitorykh) productive and creative pursuits." These were the only Ukrainian forces that were part of a "general global offensive" capable of defining the "future" ( $v$ zahalno-svitovomu nastupi na maibutnie). These have "roots in an international source" and are in "dialectical" struggle with the "national environment" (natsionalnym otochenniam); in other words, they are engaged in an "intracultural struggle" (vnutrikulturna borotba).${ }^{19}$ Semenko summarizes:

It is necessary to strenuously and seriously promote organic progressive processes in our culture, for it is not through squandering of the old but through the creation of new values that we will arrive not only in the "real Europe," but essentially [achieve] proletarian culture. ${ }^{20}$

Toward the end of the article, Semenko attributes much of what is negative in the Ukrainian cultural process (that is, the "suppression" of "experimental and innovative currents that are inevitably and organically tied to a global, intercultural, and international movement") to politics, namely, to "certain abnormalities of our leadership" (zavdiaky de-yakym nenormalnostiam kerivnytstva). ${ }^{21}$

Ukrainian Futurism fits rather neatly into the general framework of "revolution." It set out to modernize Ukrainian culture through shock therapy, using, among other things, the medium of scandal - a dramatic, almost violent act that involved toppling the national Shevchenko cult. The salvos fired in 1914 were directed at the past and in the name of the future. Like a revolution, Futurism saw part of its burden in the destruction of the status quo, which in this case meant undermining the comfort zone of readers and writers. If for some intellectuals, the Ukrainian revolution and Ukraine's liberation implied recapturing or re-establishing some purported Ukrainian national essence or authenticity, what Anthony Smith called "the 'reconstruction' of the nation," which he labeled "a species of salvation drama... based on a mythology of origins, efflorescence, decline and renewal," ${ }^{22}$ Semenko, on the other hand, tried to clear the ground for a completely new Ukrainianness, based on the foundations of the international avant-garde. A charismatic and fearless leader, he was one of those "devoured," to paraphrase Jacques Mallet du Pan, by a Revolution that rejected not only a "modern" Ukraine but also a "national" one. The

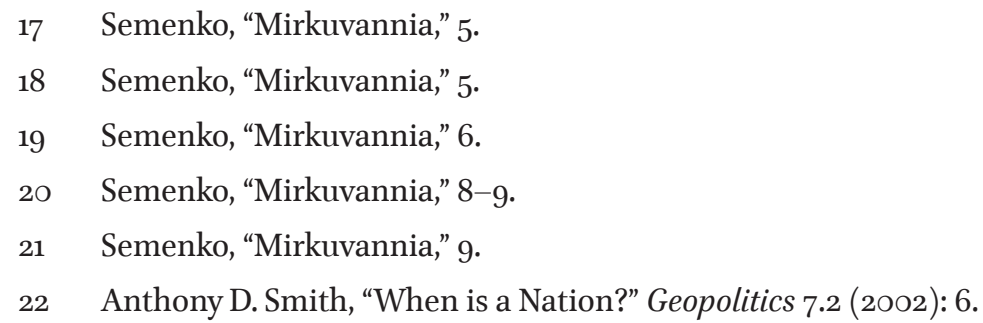


ultimate irony is that Semenko was executed by firing squad on 24 October 1937 - having been accused of Ukrainian nationalism.

\section{Bibliography}

Ilnytzkyj, Oleh S. Ukrainian Futurism, 1914-1930: A Historical and Critical Study. Cambridge, Mass.: Harvard University Press, 1997.

Semenko, Mykhail. Derzannia. Poemy [Bravado. Poems]. Kyiv: Kvero, 1914.

Semenko, Mykhail. Kvero-futuryzm. Poezopisni [Quero-Futurism. Poems-Songs]. Kyiv: Kvero, 1914. Semenko, Mykhail. "Mirkuvannia pro te, chym shkidlyvyi ukrainskyi natsionalizm dlia ukrainskoi kultury, abo chym korysnyi internatsionalizm dlia nei zh [Reflections About Why Ukrainian Nationalism is Bad for Ukrainian Culture, or, Why Internationalism is Good for It]." Bumeranh 1 (1927): 3-12.

Smith, Anthony D. "When is a Nation?" Geopolitics 7.2 (2002): 5-32.

Sriblianskyi, Mykyta. "Etiud pro futuryzm [An Etude about Futurism]." Ukrainska khata 6 (1914): 449-65.

Yevshan, Mykola. “'Suprema Lex.' Slovo pro kulturu ukrainskoho slova ['Suprema Lex.' A Word about the Culture of the Ukrainian Word]." Ukrainska khata 3-4 (1914): 236-75.

\section{(2)}

Professor Oleh S. Ilnytzkyj received his M.A. and Ph.D. from Harvard University. He taught at the University of Alberta from 1983 to 2016. His major areas of research are Modernism and the Avant-Garde, Ukrainian-Russian cultural relations, and computer-assisted text analysis. He is the author of more than 50 articles and Ukrainian Futurism, 1914-1930: An Historical and Critical Study (1997); a Ukrainian translation appeared in 2003. He is co-author (with George Hawrysch) of the four-volume Concordance to the Poetic Works of Taras Shevchenko (2001) and the Concordance to the Complete Works of Hryhorii Skovoroda (20o9, with Natalia Pylypiuk and Serhii Kozakov). He was Editor of Canadian Slavonic Papers from 2001 to January 2011, and of East/West:Journal of Ukrainian Studies from 2013-2016. 